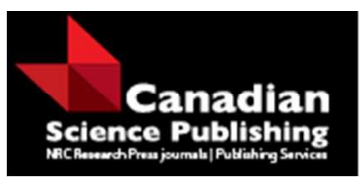

Canadian Journal of Forest Research Revue canadienne de recherche forestière

\title{
Lessons learned from oak cluster planting trials in central Europe
}

\begin{tabular}{|r|l|}
\hline Journal: & Canadian Journal of Forest Research \\
\hline Manuscript ID & cjfr-2016-0265.R1 \\
\hline Manuscript Type: & Review \\
\hline Date Submitted by the Author: & $19-$ Oct-2016 \\
\hline Complete List of Authors: & $\begin{array}{l}\text { Saha, Somidh; Albert-Ludwigs University of Freiburg, Chair of Silviculture } \\
\text { Kuehne, Christian; University of Maine, School of Forest Resources } \\
\text { Bauhus, Jüergen; Albert- Ludwigs Universty Freiburg, Chair of Silviculture }\end{array}$ \\
\hline Keyword: & $\begin{array}{l}\text { oak regeneration, tree quality and growth, species diversity and } \\
\text { productivity, plant competition, forest restoration }\end{array}$ \\
\hline
\end{tabular}

\section{SCHOLARONE ${ }^{\text {m }}$}

Manuscripts 
3 Lessons learned from oak cluster planting trials in central Europe

4

5 Somidh Saha ${ }^{1 *}$, Christian Kuehne ${ }^{1,2}$, Jürgen Bauhus ${ }^{1}$

6

$7{ }^{1}$ Chair of Silviculture, Institute of Forest Sciences, Albert-Ludwigs University of Freiburg,

8 Germany

$9 \quad{ }^{2}$ School of Forest Resources, The University of Maine, USA

10

11 *Corresponding author address and contact information: Tennenbacherstr. 4, Chair of

12 Silviculture, Albert-Ludwigs University of Freiburg, D-79106, Freiburg i. Br., Germany; Email:

13 somidhs@gmail.com, somidh.saha@waldbau.uni-freiburg.de

14 Co-authors emails:

15 Jürgen Bauhus: juergen.bauhus@,waldbau.uni-freiburg.de

16 Christian Kuehne: christian.kuehne@maine.edu

17

18

19

20

21

22

23

24 


\section{Lessons learned from oak cluster planting trials in central Europe}

\section{Abstract}

27 Oaks are becoming increasingly important for future forest management as the climate in central

28 Europe warms. Owing to the high costs of conventional row planting, artificial oak stand establishment in the form of "clusters" became popular in central Europe beginning in the 1970s. In cluster plantings, oaks are either planted in groups of ca. 20-25 at $1 \mathrm{~m}$ spacing between trees

31 (i.e. group planting), or in denser groups with 20-30 oaks $\mathrm{m}^{-2}$ (i.e. nest planting). In both cases,

32 the clusters are spaced apart at a distance that represents the target density of future crop trees. A 33 comprehensive review of the history, growth, tree quality development and economic aspects of 34 oak cluster plantings suggests that initial growing space was the most important factor 35 influencing development of oaks in clusters. Consequently, survival, growth, quality, and 36 biomass production were comparable in group and row plantings, but lower in nest plantings. In 37 addition, group plantings resulted in greater stand-level tree species diversity than nest or row 38 plantings. We conclude that oak group planting is a comparatively inexpensive option for the artificial regeneration of oak-dominated broadleaved forests for a range of situations such as 40 reforestation of disturbed areas or the afforestation of abandoned agricultural land. Future 41 research needs regarding development and tending of forests established by oak group planting 42 are highlighted.

43 Keywords: oak regeneration; tree quality and growth; species diversity and productivity; plant 44 competition; forest restoration 


\section{Introduction}

The relatively storm-resistant and moderately drought-tolerant pedunculate and sessile oak (Quercus robur L., Q. petraea (Mattuschka) Liebl.) are likely to increase in importance as the climate warms in Central Europe (Bolte et al. 2009; Roloff and Grundmann 2008; Hanewinkel et al. 2013). In addition, these two oak species are among the few tree species suitable for the production of high quality timber on sites with hydromorphic soil conditions that are prone to storm disturbance, where oaks in contrast to most other species can develop deep root systems. Hence, a quadrupling of the oak cover in the German federal state of Thuringia up to $16 \%$ of the total forested area was recommended as an adaptive management strategy against possible climate change impacts (Frischbier et al. 2010).

Oak forest cover in the former Western German states already increased by $8 \%$ or 58,536 ha from 1987 to 2002 (BMEL 2012). The observed increase in oak forest cover partly resulted from the use of oak for the reforestation of wind-thrown areas after the severe winter cyclones "in 1991 and 1999. Catastrophic damage in coniferous forests by these and subsequent storms prompted forest managers to convert pure coniferous stands established on unsuitable sites to mixed forest of oak and other broadleaved trees. As a result, the recent nationwide German forest inventory reported an additional increase in oak forest cover of $6.8 \%$ or 70,221 ha from 2002 to 2012 (BMEL 2012). This trend is likely to continue not only in Germany as it has been estimated that the total Norway spruce (Picea abies (L.) H. Karst) conversion area in 14 European countries amounts to at least 1.1 million ha (Spiecker et al. 2004). Furthermore, as part of an adaptive strategy to address predicted long-term changes in prevailing weather conditions, the

German federal state of Brandenburg has the long-term aim to convert more than 500,000 ha of 
70 pure Scots pine (Pinus sylvestris L.) stands into mixed forest with a high proportion of

71 deciduous tree species such as oak (LFE 2007).

72 Until the end of the twentieth century, oak was artificially regenerated by sowing or by planting

73 between 7,000 - 15,000 seedlings $\mathrm{ha}^{-1}$ in closely spaced rows (Burschel and Huss 1997).

74 Presently, a typical goal of commercial oak management in Germany is to produce at least 60 -

7580 high quality harvestable trees $\mathrm{ha}^{-1}$. The minimum target diameter of such trees at breast height

76 (DBH) should be $60 \mathrm{~cm}$ with a branch free bole length of $6-10 \mathrm{~m}$ at the end of a 140 to 200-

77 year rotation period (Spiecker 1991; von Lüpke 1998). Maintaining a homogenous crown layer

78 during early stand development stages by planting at high densities was a primary goal in

79 plantations managed to foster natural self-pruning and development of stem quality (Anderson

80 1951).

81 The recommended number of oak seedlings ha ${ }^{-1}$ in row planting has decreased to about 5,000

82 seedlings $\mathrm{ha}^{-1}$ since the 1990s (Ehring and Keller 2006; Guericke et al. 2008; ForstBW 2014).

83 However, high costs of site preparation, planting, fencing and tending remain a matter of

84 concern. The irregular spatial distribution of potential future crop trees, rigid thinning protocols,

85 lack of natural regeneration of other tree species, and low species diversity are further

86 undesirable attributes of this classic type of oak cultivation (Anderson 1951; Ehring and Keller

87 2006; Gockel 1995; Szymanski 1986). Overall, these factors motivated European foresters and

88 scientists to seek alternatives to the conventional row planting approach for establishing oak

89 stands.

90 Significant contributions to this search for alternatives emerged from observations of

91 regeneration dynamics in natural and semi-natural oak forests, where early stages of stand

92 development are characterized by irregularly distributed trees (Anderson 1951). One of the 
93 causes of this irregular distribution of naturally regenerated oak trees may be related to irregular 94 disturbances of the forest floor caused by wild boars (Szymanski 1986). It was assumed that the

resulting clustered distribution disappears as individual trees grow and eliminate competing neighbours. However, oak stands established in this way may lack a sufficient number of trees of desirable stem form and stability (Anderson 1951). Thus it was proposed that uniformly distributed clumps or cluster of sown or planted oaks would assure a more regular early spacing of trees and improve selection options of future crop trees (Anderson 1951; Szymanski 1986).

Several cluster planting methods, differing foremost in spacing of planted oaks as well as the number of clusters per unit area, evolved as a result of the above described theoretical considerations (Gockel 1995; Szymanski 1986). A large number of studies evaluating tree establishment, quality, growth, plant interactions, species diversity and stand productivity in early oak cluster planting trials have been published subsequently. However, effective implementation of the existing oak cluster planting methods in forest management and planning requires a comprehensive synthesis of those published findings. Consequently, the objectives of this review were to: i) provide a summary of the available published information on oak cluster planting and ii) identify research needs regarding this fairly new stand establishment technique. We start with a historical perspective, which we consider important to understand the methods of cluster planting currently applied in re- and afforestation. We then focus on synthesising the existing information on tree growth and quality, issues related to stand dynamics such as species diversity and productivity as well as economic aspects of oak cluster planting by comparing it with findings from traditional row planting. 


\section{The history of cluster planting}

\section{Nest planting}

118 Ogijewski, a forest scientist from the St Petersburg Institute of Forestry of Imperial Russia, was 119 the first to translate observations of clustered natural regeneration in oak forests into forest management practices. In 1911, he established a large-scale oak cluster trial in the Russian Tula

121 forest steppe on a clear-felled site (Pryakhin and Portnykh 1949). In that first trial, 200 122 rectangular plots or "nests" ha- (at a spacing of $7 \times 7 \mathrm{~m}$ between nests) of $2 \mathrm{~m}^{2}$ size $(1 \times 2 \mathrm{~m})$, 123 were sown with 50-100 acorns per nest. In a later modified variant, 25-50 one- or two-year-old 124 oak seedlings were planted per nest (Szymanski 1986). The nest trial of Tula became popular in 125 Russia after the communist revolution, and were widely promoted in many republics of the 126 former USSR (Buchholz 1949). The new technique was promptly adopted by the Soviet 127 agronomist Lysenko, who made it mandatory for shelter belt plantings.. As a result, thousands of 128 hectares of oak shelter belts were established on agricultural land using this technique (Lysenko 129 1949). In addition, a few forestry trials with nest plantings were established in the Tula region of 130 the Ukraine, and Belorussia, as well as close to the Russian city of Voronezh (Pryakhin and 131 Portnykh 1949; Korjakin 1952; Bodrov 1956; Zelman 1961; Tolkachev 1976). However, the fate 132 of these trials has not been properly documented.

133 Nest planting trials were first mentioned in German and British forest literature in the early 134 1950s (Anderson 1951; Buchholz 1950). Subsequently, in 1952, inspired by results from Russian 135 nest planting trials, Szymanski, a forest scientist from Poznan University, Poland, established the 136 first experimental trials of oak nest plantings outside Russia in the Siemianice forest district, 137 close to the lower Silesian highlands in south-central Poland. His modified design comprised 138 nests of $1 \mathrm{~m}^{2}$ in size that were uniformly planted with 21 one-year-old oak seedlings resulting in 
139 an inter-seedling distance of $0.2 \mathrm{~m}$ (Fig. 1). He developed two different planting protocols; either $1404 \times 4 \mathrm{~m}$ or $5 \times 8 \mathrm{~m}$ between nests with European larch (Larix decidua Mill.), small-leaved linden 141 (Tilia cordata Mill.), European beech (Fagus sylvatica L.) and sycamore maple (Acer 142 pseudoplatanus L.) trees planted in rows between the nests. Szymanski and his colleagues 143 published a series of articles on oak nest planting (Ceitel and Szymanski 1975; Szymanski 1977; 144 Szymanski 1986), and also lectured on this approach in Germany (Gussone and Richter 1994). 145 Szymanski's publications and lectures motivated forest managers and researchers in Germany to 146 trial oak nest plantings in the German states of Lower Saxony, North Rhine-Westphalia and 147 Schleswig-Holstein starting in 1986. Some trials were established on clear-felled sites and others 148 on wind-thrown areas created by the 1991 storms in the German states Rhineland-Palatinate, 149 Saxony-Anhalt, and Baden-Wuerttemberg (Dong et al. 2007a; Mangold 1988; Strobel 2000). 150 These trials did not exactly follow Szymanski's protocol. Instead, 7 x $7 \mathrm{~m}$ spacing between nests 151 gained wide acceptance (Guericke et al. 2008; Leder 2007). The space between nests was either 152 planted with shade-tolerant trainer species such as linden, hornbeam (Carpinus betulus L.), and 153 European beech or left for natural regeneration.

\section{Group planting}

156 Mark Anderson, a professor at Edinburgh University, independently developed a cluster planting 157 scheme that came to be known as “Anderson's spaced group planting” (Anderson 1930), though 158 he mentioned the Russian trials in later publications (Anderson 1951). He planted oak, European 159 beech, Scots pine, and Sitka spruce (Picea sitchensis (Bong.) Carr.) in 6 different design 160 combinations ranging from 6 to 21 trees per group. The spacing between trees inside the groups

161 was maintained at $1-2 \mathrm{~m}$ while inter-group spacing ranged from $4-7 \mathrm{~m}$. A series of spaced 
162 group plantings of conifers and broadleaves were set up in Scotland, northern England and 163 Northern Ireland in the 1930s. This spaced group planting system inspired foresters in other 164 areas and some plantations following this design were reported from the Belgian Congo (Donis 165 1956), Tunisia (Lu et al. 1975) and Malaysia (Ironside 1954). However, there is no information 166 on further developments or results from these group plantings in the United Kingdom or the 167 other countries. Apparently, the interest in spaced group planting systems among British 168 foresters waned after the 1950s due to the predominance of Sitka spruce monocultures in the 169 United Kingdom (Joyce et al. 1998). Anderson's ideas were forgotten and apparently did not 170 influence later attempts with very similar planting designs in Germany.

171 High mortality of planted seedlings in German nest planting trials established in the 1980s 172 motivated Gockel (1995) to introduce a new oak cluster planting design with a wider initial 173 spacing between the seedlings. In 1992 he planted the so-called "oak group planting" in circles 174 and squares in the Federal Forests District of Schwarzenborn in Hesse, Germany (Fig. 2). 175 Irrespective of the different group designs, the spacing between the centres of each group was 176 kept at $10 \times 10$ m resulting in 100 groups $\mathrm{ha}^{-1}$. With an initial spacing of $1 \mathrm{~m}$ between planted 177 oaks and trainer trees, taller seedlings of $80-150 \mathrm{~cm}$ in height were planted to foster survival in 178 the light of early plantation risks. In addition, the larger initial growing space of $1 \mathrm{~m}^{2}$ per 179 seedling was supposed to result in a more balanced and unrestricted initial crown development. 180 Gockel's work inspired others and led to a number of modifications to the groups involving 181 different numbers of oak seedlings as well as different numbers and species of trainer trees 182 (Harari and Brang 2008). Group planting trials were established on wind-thrown sites, clear cuts 183 and abandoned agricultural lands in Lower Saxony, Baden-Wuerttemberg, Rhineland-Palatinate, 
184 Bavaria (Ehring and Keller 2006; Petersen 2007), France (Demolis et al. 1997), Northern 185 Switzerland (Brang and Bürgi 2004) and Austria (Ruhm 1997).

\section{Success and failure of oak cluster planting}

189 Survival rate

190 The survival rate of planted trees in the first years is critical for reforestation success. Low 191 survival results in economic losses through extended rotation periods and the additional costs of 192 replacing dead trees (Margolis and Brand 1990). Hence, the survival rate of planted oaks was the 193 most common indicator of success assessed in studies comparing nest, group and row plantings.

194 The main hypothesis examined in these studies was that no difference in survival rates exists 195 between the different approaches of oak establishment. Early proponents of cluster plantings 196 claimed that intraspecific competition between oaks in nests would not affect their survival and 197 growth, that nests minimize deer browsing and offer protection from the negative effects of 198 drought, snow and frost by creating a favourable microclimate inside the clusters (Szymanski 199 1986). However, later observations from 12- to 23-year-old German nest planting trials revealed 200 that less than 50\% survived the first two decades after stand establishment, a rate significantly 201 lower than in classical row plantings (Leder 2007; Weinreich and Grulke 2001). These findings 202 were verified in a recent more comprehensive meta-analysis which reported mortality rates of 203 planted oaks in 19- to 24-year-old nest plantings to be $80 \%$ higher than for oak trees planted in 2 204 x 1 m row plantings (Saha et al. 2012). Additionally, the assumed positive effects of outer oaks 205 in nests providing protection from deer browsing to inner individuals, and favourable 206 microclimatic conditions inside clusters, could not be confirmed (Guericke et al. 2008; 
207 Weinreich and Grulke 2001). Very close initial spacing in nests triggers an early onset of shading 208 induced asymmetric competition and self-thinning among oaks. Similar phenomena have been 209 reported for other young and dense broadleaved stands (Henriksson 2001; Kint et al. 2010). In 210 contrast, no significant difference was observed in oak survival rates between group and row 211 planting (Petersen 2007). Results from previous Nelder spacing experiments also indicated that 212 initial growing space of at least $1.3 \mathrm{~m}^{2}$ is required to achieve survival rates of at least $80 \%$ in 213 planted oak stands after ca. 20 years (Nelder 1962; Gaul and Stüber 1996). The superior survival 214 rate observed in group plantings might also be partially attributable to the taller seedling size 215 used which likely resulted in reduced competition from ground vegetation and less severe 216 browsing of terminal shoots (e.g. shoulder height of the most common browser, roe deer 217 (Capreolus capreolus L.), is between 65 to $75 \mathrm{~cm}$ ) (Macdonald and Barret 1993; Dey and Parker 218 1997; Petersen 2007). Additionally, planted trainer trees in groups reduced oak mortality (Saha 219 et al. 2012).

220 In summary, based on previous analyses of oak cluster plantings it can be concluded that 221 Szymanski's (1986) assumption of similar or even slightly higher survival rates for oaks in nests 222 compared to those in rows was not corroborated. However, oak survival in group plantings was 223 satisfactory and comparable to traditional row planting.

\section{Height and DBH development}

226 One main assumption of early proponents of cluster plantings was that DBH and height growth 227 of oaks established in cluster plantings would not differ significantly from conventional row 228 planting (Szymanski 1986). However, as was subsequently shown, average DBH and height of 229 23-year-old oak trees grown in row plantings were $20 \%$ greater and $10 \%$ taller, respectively, than 
230 similar-aged oak trees from nest plantings (Guericke et al. 2008). Within nests, however, DBH 231 and height differed substantially depending on the position within the cluster. Relative 232 abundance of trees with satisfactory development was substantially lower for individuals from 233 the nest interior (Andrzejczyk and Glodowski 2010; Leder 2007). In contrast, no significant 234 difference was observed in $\mathrm{DBH}$ or height when 7- to 11-year-old group plantings were 235 compared to similar row plantings (Harari and Brang 2008; Petersen 2007). Findings were 236 confirmed in a recent meta-analysis where DBH was significantly lower by $39 \%$ in nest relative 237 to group plantings, though group and row plantings did not differ (Saha et al. 2012). Compared 238 to row planting, DBH was $29 \%$ lower in fenced nest planting trials, while in unfenced nest 239 planting trials the difference amounted to 52\%. The height of oaks did not vary significantly 240 between nest, group and the row planting counterparts. Poor diameter growth of trees in nests 241 confirms results from German oak spacing trials that found a significant decline in diameter 242 growth when initial growing space was less than $1 \mathrm{~m}^{2}$ (Gaul and Stüber 1996; Schmaltz et al. 243 1997; Spellmann and Baderschneider 1988).

244 In contrast to nest planting, the fundamental design of group plantings promotes oak diameter 245 and height growth. Older spacing experiments showed that an initial growing space of 1 to 1.5 $246 \mathrm{~m}^{2}$ per seedling reduces the impact of intraspecific competition on oak growth and promotes tree 247 quality (Schmaltz et al. 1997; Spellmann and Baderschneider 1988). This is reflected in results 248 derived from older group planting stands, where intraspecific competition did not influence 249 growth but promoted quality development (Saha et al. 2012). Nurse tree effects from early 250 successional species such as silver birch (Betula pendula Roth) and competition from naturally 251 regenerated trees of mid-successional species might also have promoted survival and tree quality 252 development in the group planting trials (Leder 1992; Leder 1996; Rock et al. 2004). However, 
253 individuals of fast growing tree species may quickly overtop oaks in groups resulting in 254 increased asymmetric competition for light and eventually hampering oak growth (von Lüpke 255 1991, 1998, 2008).

256 In conclusion, Szymanski's assumption of comparable growth of oaks growing in densely 257 planted nests and in conventionally planted rows cannot be supported. However, assessments of 258 relatively young group plantings have shown comparable diameter and height growth with row 259 planting. Initial growing space, which determines early intraspecific competition between 260 planted oaks, is therefore an important factor influencing growth of oaks in clusters.

261

262 Stability of oaks

263 Due to their habit of maintaining dry leaves during winter, young oaks can be easily physically 264 damaged during wet snow events (Röhrig et al. 2006). Physical tree stability is classically 265 assessed through the height to diameter ratio (HDR, Mosandl et al. 1991; von Lüpke 1991). Past 266 studies on oak cluster plantings had hypothesized that there were no significant differences in 267 tree stability between cluster and row plantings. However, average HDR was $20 \%$ greater in 268 trees growing in nest plantings than their row planting counterparts, while mean HDR of oaks 269 from group and row plantings were comparable (Saha et al. 2012). Poor diameter growth and 270 inferior individual tree stability in nest plantings can again be attributed to the intense initial 271 intra-specific competition (Saha et al., 2014).

272

273 Tree quality

274 Tree quality determines the value of the timber produced. Traditionally, silvicultural practices 275 during early stages of oak stand development focus on the occasional removal of poorly shaped 
276 dominant (wolf) trees. In general, management intervention is minimized to maintain a high

277 stand density and thus promote stem quality development.. During the last four decades some

278 forest scientists have stressed the importance of early positive selection of oaks with the most

279 desirable traits. To promote stem quality and to ensure that the targeted number of crop trees is

280 achieved at final harvest, it was recommended that potential future crop trees be selected in

281 young stands before they have developed the desired branch-free bole length (Leibundgut 1976;

282 Mosandl et al. 1988; Nutto 1999; Schutz 1993). However, this requires that the quality of such

283 "potential future crop trees" can be assessed before they have reached that branch-free bole

284 length. A suitable approach for assessing tree quality is based on the evaluation of individual tree 285 attributes such as stem straightness and forking (stem form), crown shape and size, as well as 286 overall branchiness, density of epicormic branches, and branch-free bole length (Leder 2007;

287 Mosandl et al. 1988). Previous studies on oak cluster plantings assessed tree quality attributes as 288 described above, and counted the number of potential future crop trees $\mathrm{ha}^{-1}$. Some of these 289 studies compared the results with findings from conventional row plantings.

291 Stem form, crown shape and branch-free bole length

292 Compared to conventional row planting, nest plantings produced $10 \%$ fewer oaks with straight, 293 upright stems and 22\% fewer trees with monopodial crowns. In group plantings, the number of 294 trees with favourable stem form or crown shape was respectively $45 \%$ and $23 \%$ greater than in 295 row planting(Guericke et al. 2008). In addition, branch free bole lengths of oaks growing in 296 groups were comparable to oaks from conventional row plantings (Harari and Brang 2008; Rock 297 2004). However, average length of the branch-free bole of oaks in nests was $41 \%$ shorter than in 298 row plantings (Saha et al. 2012). Limited growing space in nest plantings triggered intense 
299 intraspecific competition for light and caused the outermost oaks to grow outwards and develop 300 lean, crooked stems and one-sided crowns with thick lower branches (Guericke et al. 2008). This 301 was most pronounced in nest plantings without shade-providing trainer trees or where the space 302 between nests was not filled by natural regeneration of other broadleaved trees (Guericke et al. 303 2008). As a result, the most vigorous oak trees from the perimeter of nests exhibited the least 304 favourable overall quality, significantly limiting future selection options (Koch and Brang 2005). 305 The tendency of oaks to grow towards the light (Leibundgut 1976) likely resulted in the 306 dominance of poor stem forms and crown shapes in nest plantings ( Nagel and Rumpf 2010).

307 It can be concluded that intraspecific competition in nest plantings is initially very high and the 308 resulting accelerated self-thinning within individual nests provides unfavourable conditions for 309 tree quality development, because intraspecific competition is largely replaced by interspecific 310 competition (Andrzejczyk and Glodowski 2010; Saha et al. 2014). Hence, early loss of oak 311 neighbours in nests inhibits the rise of green crowns and concomitant self-pruning. In contrast, 312 the wider spacing between oaks within groups appears to maintain the initial planting pattern 313 over the first few decades of stand development and thus fosters stem quality development 314 through intraspecific interactions.

316 Number of potential future crop trees

317 Based on observations from conventional row plantings, it has been suggested previously that to 318 achieve a final number of 70 - 80 harvestable crop trees, 150 - 250 potential future crop trees ha ${ }^{-1}$ 319 would be required at age 20 (Dong et al. 2007b; Mosandl and Paulus 2002; Spellmann and von 320 Diest 1990). Several studies reported contradicting results on the number of potential future crop 321 trees identified in nest planting case studies. These numbers vary between $18-116$ crop trees ha 
$322{ }^{1}$ with only $29 \%$ of all planted oak nests having a crop tree on average (Guericke et al. 2008) to $323150-200$ crop trees $\mathrm{ha}^{-1}$ with an average of $80 \%$ of the planted oak nests having at least one 324 potential future crop tree after 10 - 20 years (Dong et al. 2007a; Leder 2007; Szymanski 1986). It 325 is not clear what the underlying reasons for the observed discrepancy might have been but 326 possible factors include differences in the removal of fast growing early-successional trees, 327 variation in tree survival rates due to browsing, use of different genetic material, and varying 328 crop tree selection criteria (Guericke et al. 2008; Gussone and Richter 1994; Nutto 2000; 329 Weinreich and Grulke 2001).

330 A comprehensive meta-analysis combining data from various sites, however, reported that the 331 proportion of potential future crop trees was $80 \%$ lower in nest planting stands than in row 332 planting counterparts (Saha et al. 2012). The same investigation also found no significant 333 difference in the number of potential future crop trees $\mathrm{ha}^{-1}$ between group and conventional row 334 plantings, an outcome that supports earlier studies (Ehring and Keller 2006; Harari and Brang 335 2008; Petersen 2007). Although the number of planted seedlings was on average nearly 40\% 336 lower in group than row planting, an equal number of potential crop trees per unit area was found 337 for both stand establishment methods. Therefore, tree quality development was much more 338 efficient in group plantings compared to conventional row planting (Demolis et al. 1997; Saha 339 2012).

\section{$341 \quad$ Necessity of trainer trees in group planting}

342 Findings from the aforementioned meta-analysis (Saha et al. 2012) suggested that trainer trees 343 likely protect inner oaks in groups and that the competition imposed by these individuals is 344 beneficial for quality development. Moreover, the protective function of trainer trees is further 
345 corroborated by the positive effect of an increasing number of initially planted trainer trees per 346 group on oak survival rate, stem form and percentage of potential future crop trees. Trainer trees 347 might have suppressed other vegetation such as Rubus spp. and the establishment of more 348 competitive tree species (Rock et al. 2004). However, no effect of planted trainer trees and 349 voluntary regeneration of mid-successional tree species on the length of the branch free bole of 350 oaks grown in groups was found (Saha et al. 2012; Saha et al. 2014). It was rather found that in 351 10- to 26-year-old oak stands and irrespective of cluster or row planting, self-pruning of oaks 352 triggered by intraspecific competition would suffice for tree quality development. The observed 353 positive effect of trainer trees in group plantings thus was not a species-specific influence but 354 rather a facilitative effect of additional trees. As stands become older, these trainer trees can 355 develop into strong competitors for oaks (Saha et al. 2014). Thus they should be monitored and 356 possibly removed or preferably coppiced, if they overgrow the oaks in clusters (Joyce et al. 357 1998; Otto et al. 2009).

358 In conclusion, studies evaluating quality development in oak cluster plantings clearly 359 demonstrated that stem quality development is inferior in nest compared to row plantings. In 360 contrast, promising results have been obtained for oaks established in groups. However, further 361 studies are required in older group planting trials to monitor how oak tree quality proceeds with 362 stand development and under varying site and stand conditions.

Economic aspects

366 In comparison to conventional row planting, cluster planting systems may be financially 367 advantageous owing to a reduction in the number of planted seedlings and lower expenses for 
368 site preparation, tending, and protection measures (Szymanski 1986). Only few studies have 369 compared establishment and tending costs of cluster and row plantings while there are no cost 370 analyses that compare group and nest plantings. A substantial reduction in establishment 371 expenses of up to $50 \%$ was found in studies that compared oak group and conventional row 372 plantings (Gockel et al. 2001; Weinreich and Grulke 2001). However, given the general trend to 373 reduce seedling numbers in artificial regeneration, this advantage of cluster plantings may be 374 gradually disappearing (Kühne et al. 2014). Recent guidelines by some German state forest 375 administrations and institutions regarding initial seedling numbers for wide-spaced oak row 376 plantings (e.g. 3 × $1 \mathrm{~m}$ initial spacing, i.e. 3300 seedlings ha ${ }^{-1}$ ) would significantly reduce the 377 establishment costs (Nutto 2000; Ehring and Keller 2006; Guericke et al. 2008; ForstBW 2014).

378 Wide initial spacing, however, has a detrimental effect on overall stem quality due to delayed 379 self-pruning (Kuehne et al. 2013). Artificial pruning may be required in such situations to 380 achieve a sufficient number of potential future crop trees. Whether or not later pruning activities 381 would offset the cost saved by low density row planting has not been studied. Furthermore, the 382 presence of a sufficient number of additional seedlings between clusters has been highly 383 recommended to promote the development of favourable stem qualities, particularly in oak 384 stands established through nest planting (Gussone and Richter 1994). If these supplementary 385 seedlings do not regenerate naturally and in high enough density, as has been often observed, 386 they need to be planted (Leder 2007). Hence, whether cluster and especially nest plantings are 387 more cost-efficient than row plantings or not depends on the reference used for comparison. In 388 cases, where clusters need to be complemented with planting of additional trees between 389 clusters, or when clusters are compared to low density row planting, they are likely not more cost 390 efficient in the establishment phase. 
391 The number of clusters to be planted can also be optimized to reduce costs without hampering

392 silvicultural goals. Forest managers in southwestern Germany, for example, currently plant 40 to

39370 clusters $\mathrm{ha}^{-1}$ instead of the 100 proposed originally (Ehring and Keller 2006; Saha 2012;

394 Kühne et al. 2014). The number of groups could be further reduced if sufficient natural

395 regeneration of desirable tree species establishes between the clusters in a timely manner

396 (Gockel et al. 2001). A low number of clusters per unit area further offers reduction in stand

397 establishment expenses as site preparation activities can be limited to the few cluster locations.

398 This holds especially true for wind thrown sites where costly broad-scale residue and slash

399 removal as well as soil alteration necessary for mechanical row planting can be neglected.

400 However, whether a reduction in the number of clusters is economically beneficial, depends not

401 only on the savings in establishment costs but also the subsequent costs and tree volume and

402 value production.

403 Early advocates of the cluster design also predicted reductions in tending costs in young stands

404 because weeding and tending operations were supposed to focus only on planted nests or groups

405 whereas in traditional row plantings, the entire planted area requires such expensive treatments

406 (Szymanski 1994). However, other studies of oak nest plantings called for early tending

407 operations such as the removal of naturally regenerated early successional species to secure the

408 long-term management goal (Dong et al. 2007a; Guericke et al. 2008). However, for nest

409 plantings, there have been no economic assessments on subsequent tending operations. No

410 significant difference in tending expenses were found for 7-year-old Swiss oak group planting

411 trials when compared with similar aged row plantings (Koch and Brang 2005). In contrast,

412 higher costs when compared to row planting have been incurred for the time-consuming search

413 of groups and their marking where they were embedded in vigorous competing vegetation 
414 without uniform spacing or proper marking (e.g. wooden poles in the centre of the group as a 415 marker) (Ehring and Keller 2006).

416 In summary, oak group plantings are likely more cost-efficient if large-scale site preparation 417 measures are needed to conduct mechanical row planting (Petersen 2007). Cost efficiency in 418 group plantings can be increased further by reducing the number of groups to be planted per unit 419 area, and by regular spacing between groups. However, differences in tending expenses between 420 group and row plantings are not yet apparent at this early stage of existing trials; therefore, 421 further investigations on subsequent tending measures in older group plantings are needed.

423 Tree species diversity and stand productivity in cluster planting

424 The area between clusters, on average almost two thirds of the stand area in cluster plantings, 425 remains for natural regeneration. The establishment of early- and mid-successional tree and 426 shrub species in the interspaces between clusters has been prolific in formerly forested sites that 427 are surrounded by remaining forests (Saha et al. 2013). Several studies in Central European 428 forests have shown that diverse tree communities comprising mostly early-successional woody 429 species can establish in extensively treated or unmanaged clear-felled and wind-thrown areas 430 (Jonasova et al. 2010; Wohlgemuth et al. 2002). This voluntary regeneration significantly 431 increased species diversity in cluster plantings when compared to row planting counterparts. 432 Cluster planting in areas embedded in a matrix of existing forests provides ample opportunities 433 for the establishment of diverse tree species communities at early stages of stand development 434 (Saha 2012). Natural regeneration between clusters may be much lower when afforesting 435 abandoned agricultural land, where fewer tree propagules are available or vigorous ground 
436 vegetation inhibits establishment of woody plants. However, there is limited information on

437 natural regeneration in cluster planting stands established on abandoned agricultural land.

438 Naturally regenerated early- and mid-successional species contributed almost half of total stand

439 basal area in cluster plantings and thus compensated for the reduced number of oaks in group

440 plantings (Saha et al., 2013). Moreover, the observed increase in tree species diversity had a

441 positive effect on stand basal area which confirms results of previous studies on diversity-

442 productivity relationships in temperate forest ecosystems in Europe (Morin et al. 2011; Vila et al.

443 2007). This diversity effect may be caused by the complementarity resource use of species that

444 differ in height growth and shade-tolerance leading to canopy stratification (Bauhus et al. 2004;

445 Körner 2005; Morin et al. 2011). Belowground niche separation between fine roots of oaks and

446 other species and nurse tree effects by early successional trees (e.g. silver birch) might further

447 facilitate efficient resource use in cluster planting stands (Saha et al. 2014, Stark et al. 2014).

448 However, these belowground interactions between oaks and naturally regenerated trees are

449 largely unexplored.

450 Early successional tree species increase total forest diversity leading to more complex food webs

451 (Swanson et al. 2010). The promotion of these species as an integral component of forest

452 management practices was thus recommended to enhance ecosystem services of managed forests

453 in central Europe (Reif and Walentowski 2008). However, growth of commercially important

454 species (e.g. oaks) may be hampered by these fast growing species, thus they were usually

455 removed as part of early stand tending in conventionally managed stands. Cluster planting

456 schemes offer an opportunity to avoid these undesired interspecific interactions by spatially

457 separating planted oak clusters and areas left for natural regeneration of other woody species

458 during the first few decades of stand development. Moreover, by varying the number of groups 
459 per unit area and therefore the distance between groups the cluster planting design can be 460 adjusted to vary the proportions of oak and other species.

461 Some forest practitioners argue that the diversification of forest stands may complicate future 462 management (Kerr 1999). However, in cluster planting, managers only need to focus on potential 463 future crop trees emerging from each cluster. Tending operations to remove naturally 464 regenerated competitors can focus on the interior and the periphery of clusters (Saha et al. 2014) 465 (Fig. 3). The remaining vegetation between the clusters therefore could be maintained and 466 managed for the promotion of biodiversity, the production of biomass or high value logs from 467 species like silver birch, wild cherry (Prunus avium L.), or sycamore maple (Fig.3).

\section{Risks and benefits of cluster planting - an outlook}

471 Every forest management system needs defined targets for guidance and to evaluate management

472 success. However, inherent potential risks may hamper the achievement of those targets, in

473 particular in natural and semi-natural systems that are not under strict human control. Potential

474 future crop trees are such a potential target in oak stands managed for high value timber 475 production (Abetz and Kladtke 2002). How many future crop trees per unit area are needed after 476 the first commercial thinning, which commonly takes place in 35 to 50 -year-old stands, is a 477 matter of ongoing debate. Whereas the aim may be to obtain between 60 - 80 harvestable oak 478 trees $\mathrm{ha}^{-1}$ at the end of the rotation, the question is whether a substantial number of reserve future 479 crop trees are required to achieve that target. A study on the development of potential future crop 480 trees in oak stands established by row planting showed that $9-14 \%$ of such trees either died (by 481 pathogen attack, wind and snow damage) or were downgraded in quality (e.g. epicormic 
482 sprouting) (Spellmann and von Diest 1990a). However, a loss in future crop trees is sometimes

483 seen as the result of flawed management decisions during early selection, promotion and tending

484 rather than a failure of the silvicultural system oriented towards future crop trees (Abetz 1980;

485 Abetz and Ohnemus 1999).

486 The special situation in cluster planting stands is that after the first commercial thinning there

487 will be at most only one future oak crop tree for each initially planted cluster. Any further 488 mortality of crop trees or downgrading owing to poor development in tree quality will 489 immediately affect the overall silvicultural aim and likely the economic outcomes. 490 Unfortunately, there is no information regarding the mortality rates of future crop trees from 491 cluster-plantings, since existing trials have not yet reached the age of first commercial thinning.

492 It is clear that the solution to the potential risk of losing future crop trees that have emerged from 493 clusters at later stages of stand development cannot simply be an increase in the number of 494 clusters. Though this would diminish cost savings gained through planting fewer trees and 495 benefits of increased tree species diversity, increased numbers of clusters would result in 496 insufficient spacing between crop trees in areas where no mortality occurs. The above 497 mentioned risk of low numbers of potential future crop trees may also be compensated by 498 increasing the distance between groups and between-group planting of fast-growing valuable 499 conifers or broadleaves (e.g. Douglas-fir (Pseudotsuga menziesii (Mirb.) Franco) or wild cherry) 500 between groups. This can be an attractive option for forest owners interested in developing 501 mixed forests and obtaining early financial returns. . Responses from several foresters in Baden502 Wuerttemberg and Lower Saxony, Germany revealed that 40 - 50 harvestable oak trees instead 503 of $80-100$ oaks ha $^{-1}$ would be an acceptable number, if high value trees of other species and/or a 504 sufficient biomass from fast-growing species (e.g. European aspen (Poplus tremula L.) and silver 
505 birch) can be produced from cluster planting stands in shorter periods. However, these 506 alternative options have not been assessed through economic modeling. This risk can also be 507 mitigated if additional crop trees can be designated from natural regeneration occurring between 508 groups. However, information on this is lacking.

510 Cluster planting with other species

511 So far cluster planting studies were carried out for artificial regeneration of oaks. However, 512 cluster plantings offer similar benefits and may be equally suitable for other species. In 513 particular, cluster planting can be used for regeneration of other broadleaved species which 514 require appropriate neighbourhood density to facilitate self-pruning of the lower trunk.

515 Besides the focus on high-quality timber production, cluster planting methods can also be used to 516 pursue other forest management objectives followed by as afforestation and restoration. For 517 example, large afforestation programs (e.g. bottomland afforestation program in eastern 518 Mississippi, USA) often have a shortage of funds and are thus forced to plant trees at wide 519 spacing to achieve area targets with the consequence of the development of trees with low stem 520 quality (Lockhart et al., 2006; Dey et al., 2010). In such situations, planting in groups would not 521 only provide an appropriate initial growing space for such species but ensure that large areas can 522 be covered with limited numbers of plants. Some abandoned agricultural lands have already been 523 successfully restored in Germany using the group planting method (Ehring and Keller 2006; 524 Petersen 2007). A relatively similar low density cluster planting design of holm oak (Quercus 525 ilex L.) described as "woodland islets" was successfully used for afforestation purposes on 526 degraded land in Spain (Benayas et al. 2008). Cluster plantings of various coniferous species 527 were also recommended to restore Swiss high-elevation mountain forests (Schöneberger 2001). 
528 Recently, cluster plantings of silver fir (Abies alba Mill.) and Pilgerodendron (Pilgerodendron

529 uviferum (D. Don) Florin) were trialled in Italy and Chile, respectively, for the purpose of forest

530 restoration (Bannister 2015; Fiorentini et al. 2015; Bannister et al. 2016).

531

532

533 Conclusions

534 Based on the results presented in this review, we conclude that the success of oak cluster 535 plantings depends on a number of factors, most importantly the planting density within clusters. 536 The nest planting approach is not a suitable option for oak stand establishment aiming at 537 valuable timber production. In contrast, oak group planting with 1900 to 3100 seedlings ha ${ }^{-1}$ can

538 be used as an alternative to traditional row planting with ca. 5,000 seedlings ha $^{-1}$. Group planting 539 represents a reforestation method that not only offers the opportunity to produce high quality oak 540 timber, but promotes natural regeneration of additional tree species between the groups. This 541 increases woody species diversity and possibly also productivity, and allows natural successional 542 processes to take place. This review also shows that forestry trials which are commonly cost 543 intensive and often forgotten in the course of time, sometimes regain importance as societal and 544 economic demands in relation to forests change (Powers 1999). We showed that initial growing 545 space initial size of the seedlings, and presence of trainer trees are crucial factors for the 546 successful establishment and subsequent qualification of oaks in cluster plantings. Future 547 research should focus on the tending, cost-benefit analyses and modeling of growth dynamics of 548 group planting stands. 


\section{Acknowledgements}

We thank the German Academic Exchange Service (DAAD) for providing a doctoral fellowship (A/07/71389) to the first author. We are also thankful to the Graduate School "Environment, Society and Global Change" of University of Freiburg and the Forest Administration of Rhineland-Palatinate for providing financial support. We also acknowledge valuable comments from two reviewers that improved our paper. SS performed the literature review and wrote the manuscript. CK and JB provided ideas for the manuscript and co-wrote it. JB provided doctoral supervision to SS.

\section{References}

Abetz, P. 1980. Zum Konzept einer Z-Baum-orientierten Kontrollmethode. Allgemeine Forstund Jagdzeitung 151 (4/5): 65-58.

Abetz, P., and Kladtke, J. 2002. The target tree management system. Forstwiss. Cent.bl. 121(2): 73-82.

Abetz, P., and Ohnemus, K. 1999. Varification of the future-crop-tree-norms (ZB-norm) for beech in a thinning experiment. Allgemeine Forst- und Jagdzeitung 170(9): 157-165.

Anderson, M.L. 1930. A New System of Planting. Scottish Forestry Journal 44(2): 78-89.

Anderson, M.L. 1951. Spaced group-planting and irregularity of stand-structure. Empire Forestry Journal 30(4): 328 - 341.

Andrzejczyk, T., and Glodowski, Z. 2010. Effect of admixture species on the growth of pedunculate oak (Quercus robur L.) in a plantation established using the Szymanski Method. Forest Research Papers 71(4): 321-330.

Bannister, J.R. 2015. Recuperar bosques no es solo plantar árboles: lecciones aprendidas luego de 7 años restaurando bosques de Pilgerodendron Uviferum (D. Don) Florin en Chiloé. Anales del Instituto de la Patagonia 43(1): 35-51.

Bannister, J.R., Donoso, P., Mujica, R. 2016. La Silvicultura como herramienta para la restauración de bosques templados. Bosque 37(2): 229 - 235. 
Bauhus, J., van Winden, A.P., and Nicotra, A.B. 2004. Aboveground interactions and productivity in mixed-species plantations of Acacia mearnsii and Eucalyptus globulus. Can. J. For. Res.-Rev. Can. Rech. For. 34(3): 686-694.

Benayas, J.M.R., Bullock, J.M., and Newton, A.C. 2008. Creating woodland islets to reconcile ecological restoration, conservation, and agricultural land use. Front. Ecol. Environ. 6(6): 329336.

BMEL (Bundesministerium für Ernährung und Landwirtschaft). 2012. Bundeswaldinventur. Available from www.bundeswaldinventur.de (accessed 17 Oct 2016).

Bodrov, V.A. 1956. The prospects of raising Oak by the nest method. [Russian]. Agrobiologija (Agrobiology). 5: 142-144.

Bolte, A., Ammer, C., Lof, M., Madsen, P., Nabuurs, G.J., Schall, P., Spathelf, P., and Rock, J. 2009. Adaptive forest management in central Europe: Climate change impacts, strategies and integrative concept. Scand. J. Forest Res. 24(6): 473-482.

Brang, P., and Bürgi, A. 2004. Trupppflanzung im Test. Zürcher Wald 36(5): 13-16.

Buchholz, A. 1949. Neue Strömungen in der sowjetischen Waldwirtschaft. Zeitschrift für Weltforstwirtschaft 13: 131-139.

Burschel, P., and Huss, J. 1997. Grundriss des Waldbaus: ein Leitfaden für Studium und Praxis. Parey, Berlin. pp 487.

Ceitel, J., and Szymanski, S. 1975. Biological and economic effectiveness of methods of nest planting for the establishment of Oak in mixed plantations. [Polish]. Prace Komisji Nauk Rolniczych i Komisji Nauk Lesnych. 40: 3-19

Demolis, C., François, D., and Delannoy, L. 1997. Que sont devenues les plantations de feuillus par points d'appui? Office National des Forêts, Bulletin Technique. 32: 27-37.

Dey, D.C., and Parker, W.C. 1997. Morphological indicators of stock quality and field performance of red oak (Quercus rubra L.) seedlings underplanted in a central Ontario shelterwood. New For. 14(2): 145-156.

Dey, D.C., Gardiner, E.S., Kabrick, J.M., Stanturf, J.A., and Jacobs, D.F. 2010. Innovations in afforestation of agricultural bottomlands to restore native forests in the eastern USA. Scand. J. Forest Res. 25: 31-42.

Dong P.H., Eder W, and Muth M. 2007a. Eichen-Nesterpflanzungsversuche in Rheinland-Pflaz Ergebnisse eines 15jährigen Beobachtungszeitraums. In Eiche im Pfälzerwald. Forsschunganstalt für Waldökologie und Forstwirtschaft Rheinland-Pflaz, Trippstadt. pp. 4-22.

Dong P.H., Eder W, and Muth M. 2007b. Traubeneichen-Läuterungsversuche im Pfälzerwald. In Eiche im Pfälzerwald. Mitteilungen aus der Forschungsanstalt für Waldökologie und Forstwirtschaft Rheinland-Pfalz. Trippstadt. pp. 57-77. 
614 Donis, C. 1956. Closed forest of the Belgian Congo and the present position of its silviculture. 615 [French]. Bull. agric. Congo belge. 47(2): 261-320.

616 Ehring, A., and Keller, O. 2006. Eichen-Trupp-Pflanzung in Baden-Württemberg. AFZ/Der 617 Wald 61: 491-494.

618 Fiorentini, S., Degl'Innocenti, N., Bartolozzi, L., Galipa, G., Travaglini, D., and Nocentini, S. 619 2015. Deer impact on silver fir artificial regeneration. First results of a cluster planting trial. 620 Italian Journal of Forest and Mountain Environments 70(2): 83-98.

621 ForstBW (Landesbetrieb Forst Baden-Württemberg) 2014. Richtlinie landesweiter

622 Waldentwicklungstypen. Available from

623 www.forstbw.de/fileadmin/forstbw_infothek/forstbw_praxis/wet/ForstBW_Waldentwicklung_w 624 eb.pdf (accessed 17 Oct 2016).

625 Frischbier, N., Profft, I., and Arenhövel, W. 2010. Die Ausweisung klimawandelangepasster 626 Bestandeszieltypen für Thüringen. Forst und Holz 65(2): 28 - 35.

627 Gaul, T., and Stüber, V. 1996. Der Eichen-Nelder-Verbandsversuch Göhrde. Forst und Holz 51: $628 \quad 70-75$.

629 Gockel, H. 1995. Die Trupp-Pflanzung, Ein neues Pflanzschema zur Begründung von 630 Eichenbeständen. Forst und Holz 50: 570 - 575.

631 Gockel, H., Rock, J., and Schulte, A. 2001. Aufforsten mit Eichen-Trupppflanzungen. AFZ/Der 632 Wald 56: 223-226.

633 Guericke, M., Petersen, R., and Blanke, S. 2008. Wachstum und Qualität von Eichennestern in 634 Nordwestdeutschland. Forst und Holz 63(6): 58-63.

635 Gussone, H., and Richter, A. 1994. Eichen-Nester - Zweiter Bericht der Versuche mit 636 Nesterpflanzungen in Norddeutschland. Forst- und Holzwirt 49(11): 300-304.

637 Hanewinkel, M., Cullmann, D.A., Schelhaas, M.J., Nabuurs, G.J., and Zimmermann, N.E. 2013. 638 Climate change may cause severe loss in the economic value of European forest land. Nat. Clim. 639 Chang. 3(3): 203-207.

640 Harari, O. and Brang, P. 2008. Trupppflanzungs-Experimente mit Stieleiche und Bergahorn in 641 der Schweiz. Ergebnisse der Erhebungen 2007. Eidg. Forschungsanstalt für Wald, Schnee und 642 Landschaft (WSL). Birmensdorf. pp 24.

643 (http://www.wsl.ch/fe/waldressourcen/projekte/trupppflanzungen/downloads/trupppflanzungsexp 644 erimente_eiche_ahorn). Last accessed on 16.10.2016.

645 Henriksson, J. 2001. Differential shading of branches or whole trees: survival, growth, and 646 reproduction. Oecologia 126(4): 482-486.

647 Ironside, G.E. 1954. Spaced group planting. Malayan Forester. 17: 203-206. 
674

675

676

677

678

679

680

681

682

683
Jonasova, M., Vavrova, E., and Cudlin, P. 2010. Western Carpathian mountain spruce forest after a windthrow: Natural regeneration in cleared and uncleared areas. For. Ecol. Manage. 259(6): 1127-1134.

Joyce, P.M., Huss, J., McCarthy, R., Pfeifer, A., and Hendrick, E. 1998. Growing broadleaves COFORD, Dublin.pp. 144

Kerr, G. 1999. The use of silvicultural systems to enhance the biological diversity of plantation forests in Britain. Forestry 72(3): 191-205.

Kint, V., Hein, S., Campioli, M., and Muys, B. 2010. Modelling self-pruning and branch attributes for young Quercus robur L. and Fagus sylvatica L. trees. For. Ecol. Manage. 260(11): 2023-2034.

Koch, R., and Brang, P. 2005. Extensive Verjüngungsverfahren nach Lothar. Schlussbericht zuhanden der Eidg. Forstdirektion des BUWAL. Eidg. Forschungsanstalt für Wald, Schnee und Landschaft (WSL). Birmensdorf. pp 90.

(http:/www.wsl.ch/fe/waldressourcen/projekte/trupppflanzungen/downloads/schlussbericht_buw al_2005). Last accessed on 16.10.2016.

Korjakin, D.A. 1952. Characteristics of the growth of oak in plantations established by Ogievskii's method. [Russian]. Lesnoe Khozyaistvo. 5(11): 16-19

Körner, C. 2005. An introduction to the functional diversity of temperate forest trees. In Forest Diversity and Function: Temperate and Boreal Systems. Edited by M. Scherer-Lorenzen, C. Körner, and E-D. Schulze. Springer-Verlag Berlin, Berlin. pp. 13-37.

Kuehne, C., Kublin, E., Pyttel, P., and Bauhus, J. 2013. Growth and form of Quercus robur and Fraxinus excelsior respond distinctly different to initial growing space: results from 24-year-old Nelder experiments. Journal of Forestry Research. 24(1): 1-14.

Kühne, C., Jacob, A., Gräf, M., 2014. The practice of establishing and tending oak (Qercus petraea [Matt.] Liebl., Q. robur L.) stands - An interview-based study in the eastern Upper Rhine Plain, Germany [German]. Forstarchiv 85: 179-187. In German.

Leder, B. 1992. Weichlaubhölzer: Verjüngungsökologie, Jugendwachstum und Bedeutung in Jungbeständen der Hauptbaumarten Buche und Eiche. Schriftenreihe der Landesanstalt für Forstwirtschaft Nordrhein-Westfalen, Sonderband, pp 416.

Leder, B. 1996. Weichlaubhölzer im Eichen- und Buchen-jungbeständen. Forst und Holz 51(10).

Leder, B. 2007. Wachstum und qualitative Entwicklung von Eichennestern. AFZ/Der Wald 62(8): 420-423.

Leibundgut, H. 1976. Grundlagen zur Jungwaldpflege - Ergebnisse zwanzigjähriger Untersuchungen über die Vorgänge der Ausscheidung, Umsetzung und Qualitätsentwicklung in jungen Eichenbeständen. Mitteilungen Eidgenössische Anstalt für das Forstliche Versuchswesen 52(4): 311-371. 
684 LFE. 2007. Waldumbaupotential im Land Brandenburg, Wald im Klimawandel - Risiken und 685

686

687

688

689

690

691

692

693

694

695

696

697

698

699

700

701

702

703

704

705

706

707

708

709

710

711

712

713

714

715

716

717

Anpassungsstrategien. Eberswalder Forstliche Schriftenreihe 42: 144.

Lockhart, B.R., Ezell, A.W., Hodges, J.D., and Clatterbuck, W.K. 2006. Using natural stand development patterns in artificial mixtures: A case study with cherrybark oak and sweetgum in east-central Mississippi, USA. For. Ecol. Manage. 222(1-3): 202-210.

Lu, C.M., Lee, H.T., and Rin, U.C. 1975. Planting in widely spaced groups: a promising technique for enriching the maquis [French]. In Bulletin d'Information Institut National de Recherches Forestieres, Tunisia.

Lysenko, T.D. 1949. Experimental sowing of forest belts in clusters [Russian]. Sovetskaya Agronomiya. 3: 4-17.

Macdonald, D.W. and Barrett , P. 1993. Mammals of Europe. New Jersey. Princeton University Press. pp. 448.

Mangold, S. 1988. Versuche mit Eiche-Nesterpflanzungen. Forst und Holz 43(18): 460-461.

Margolis, H.A., and Brand, D.G. 1990. An ecophysiological basis for understanding plantation establishment. Can. J. For. Res.-Rev. Can. Rech. For. 20(4): 375-390.

Morin, X., Fahse, L., Scherer-Lorenzen, M., and Bugmann, H. 2011. Tree species richness promotes productivity in temperate forests through strong complementarity between species. Ecol. Lett. 14(12): 1211-1219.

Mosandl, R., Burschel, P., and Sliwa, J. 1988. Die Qualität von Auslesebäumen in Eichenjungbeständen. Forst und Holz 43: 37-41.

Mosandl, R., Elkateb, H., and Ecker, J. 1991. Investigations of various thinning treatments in young oak stands. Forstwiss. Cent.bl. 110(6): 358-370.

Mosandl, R., and Paulus, F. 2002. Rationelle Pflege junger Eichenbestände. AFZ/Der Wald 57: 581-584.

Nagel , R.V., and Rumpf, H. 2010. Der Eichenverbandsversuch Ahlhorn: Ergebnisse nach 35jähriger Beobachtungsdauer. Forst und Holz 65(3): 14-19.

Nelder, J. A. 1962. New kinds of systematic designs for spacing experiments. Biometrics 18 : $283-307$.

Nutto, L. 1999. Neue Perspektiven für die Begründung und Pflege von jungen Eichenbeständen.Ergebnisse einer Untersuchung zur Kronenentwicklung, Astreinigung und Dickenwachstum junger Stiel- und Traubeneichen in Europa. Freiburger Forstliche Forschung 5: 147-150.

Nutto, L. 2000. Wachstum und Qualität von Eichen aus Nesterpflanzung. AFZ/Der Wald 55(8): 401-403. 
Otto, D., Wagner, S., and Brang, P. 2009. Konkurrenz zwischen Stieleiche und Buche auf Lothar-Sturmflächen. Schweizerische Zeitschrift für Forstwesen 160(5): 114-123.

Petersen, R. 2007. Eichen-Trupp-Pflanzung - erste Ergebnisse einer Versuchsfläche im NFA Neuhaus. Forst und Holz 62(3): 19-25.

Powers, R.F. 1999. If you build it, will they come? Survival skills for silvicultural studies. For. Chron. 75(3): 367-373.

Pryakhin, I.P., and Portnykh, Y.P. 1949. Patch methods of raising oak from shelterbelts. [Russian]. Agrobiologija (Agrobiology). 1:75-84.

Reif, A., and Walentowski, H. 2008. The assessment of naturalness and its role for nature conservation and forestry in Europe. Waldökologie, Landschaftsforschung und Naturschutz. 6: $63-76$.

Rock, J. 2004. Zur Entwicklung der Astdurchmesser junger Eichen in Trupppflanzungsbeständen. Forstarchiv 75: 143-149.

Rock, J., Puettmann, K.J., Gockel, H.A., and Schulte, A. 2004. Spatial aspects of the influence of silver birch (Betula pendula L.) on growth and quality of young oaks (Quercus spp.) in central Germany. Forestry 77(3): 235-247.

Röhrig, E., Bartsch, N., and Lüpke, von. B. 2006. Waldbau auf ökologischer Grundlage. Eugen Ulmer, Stuttgart. pp 479.

Roloff, A., and Grundmann, B. 2008. Bewertung von Waldbaumarten anhand der KlimaArtenMatrix. AFZ/Der Wald 63: 1086-1088.

Ruhm, W. 1997. Alternative - Kulturbegründung von Eichenmischwald. Österreichische Forstzeitung 108(7): 29.

Saha, S. 2012. Development of tree quality, productivity, and diversity in oak (Quercus robur and Q. petraea) stands established by cluster planting. Ph.D. Dissertation. Institute of Silviculture. University of Freiburg, Freiburg, Germany. pp. 130. (https://www.freidok.unifreiburg.de/fedora/objects/freidok:9960/datastreams/FILE1/content). Last accessed on 16 Oct 2016.

Saha, S., Kuehne, C., and Bauhus, J. 2013. Tree Species Richness and Stand Productivity in Low-Density Cluster Plantings with Oaks (Quercus robur L. and Q. petraea (Mattuschka) Liebl.). Forests 4(3): 650-665.

Saha, S., Kuehne, C., and Bauhus, J. 2014. Intra- and interspecific competition differently influence growth and stem quality of young oaks (Quercus robur L. and Quercus petraea (Mattuschka) Liebl.). Ann. For. Sci. 71(3): 381-393.

Saha, S., Kuehne, C., Kohnle, U., Brang, P., Ehring, A., Geisel, J., Leder, B., Muth, M., Petersen, R., Peter, J., Ruhm, W., and Bauhus, J. 2012. Growth and quality of young oaks 
753 (Quercus robur and Q. petraea) grown in cluster plantings in central Europe: a weighted meta754 analysis. For. Ecol. Manage. 283: 106-118.

755 Schmaltz, J., Fröhlich, A., and Gebhardt, M. 1997. Die Qualitätsentwicklung in jungen 756 Traubeneichenbeständen im Hessischen Spessart. Forstarchiv 68(1): 3-10.

757 Schonenberger, W. 2001. Cluster afforestation for creating diverse mountain forest structures - a 758 review. For. Ecol. Manage. 145(1-2): 121-128.

759 Schutz, J.P. 1993. High-quality oak silviculture in Switzerland - concepts of education and 760 production in the marginal range of European oak. Ann. Sci. For. 50(6): 553-562.

761 Spellmann, H., and Baderschneider, A. 1988. Erste Auswertung eines Traubeneichen762 Pflanzverbands-und Sortimentsversuches im Forstamt Hardegsen/Solling. Forst und Holz 19: $763 \quad 447-450$.

764 Spellmann, H., and von Diest, W. 1990. Entwicklung von Z-Baum-Kollektiven in langfristig 765 beobachteten Eichenversuchsflächen. Forst und Holz 19: 573-580.

766 Spiecker, H. 1991. Controlling the diameter growth and the natural pruning of Sessile and 767 Pedunculate oaks (Quercus petraea (MATT.) LIEBL. and Quercus robur L.). Schriftenreihe der 768 Landesforstverwaltung Baden-Württemberg, Stuttgart. 72: 1 - 135

769 Spiecker, H., Hansen, J., Klimo, E., Skovsgaard, J.P., Sterba, H., and von Teuffel, K. (eds). 770 2004. Norway spruce conversion-Options and consequences. EFI Research Reports No. 18. Brill 771 Academy, Leiden, The Netherlands. pp. 269.

772 Stark, H., Nothdurft, A., Block, J., and Bauhus, J. 2015. Forest restoration with Betula ssp and 773 Populus ssp nurse crops increases productivity and soil fertility. For. Ecol. Manage. 339: 57-70.

774 Strobel, G. 2000. Eichen-Biogruppen. AFZ/Der Wald 55(8): 396 - 398.

775 Swanson, M.E., Franklin, J.F., Beschta, R.L., Crisafulli, C.M., DellaSala, D.A., Hutto, R.L., 776 Lindenmayer, D.B., and Swanson, F.J. 2010. The forgotten stage of forest succession: early777 successional ecosystems on forest sites. Front. Ecol. Environ. 9(2): 117-125.

778 Szymanski, S. 1977. Application of Ogijevski's nest method of artificial regeneration of oak on 779 fertile sites. [Polish]. Sylwan. 121(9): 43-55.

780 Szymanski, S. 1986. Die Begründung von Eichenbeständen in "Nest-Kulturen". Forst- und 781 Holzwirt 41(1): 3-7.

782 Szymanski, S. 1994. Ergebnisse zur Begründung von Eichenbeständen durch die Nestermethode. 783 Beitr.Forstwirtsch.u.Landsch.ökol. 28(4): 160-164.

784 Tolkachev, L.N. 1976. Comparative yield of line plantations and 'nest' plantations of oak. 785 [Russian]. Lesnoe Khozyaistvo 6: 36-38. 
801

802

803

804

805

806

807

808

809

810

811

812
Vila, M., Vayreda, J., Comas, L., Ibanez, J.J., Mata, T., and Obon, B. 2007. Species richness and wood production: a positive association in Mediterranean forests. Ecol. Lett. 10(3): 241-250.

von Lüpke, B. 1991. Influence of competition by broadleaf pioneers on growth of young sessile oaks [German]. Forst und Holz 46: 166-171.

von Lüpke, B. 1998. Silvicultural methods of oak regeneration with special respect to shade tolerant mixed species. For. Ecol. Manage. 106(1): 19-26.

von Lüpke, B. 2008. Einfluss unterschiedlicher Hiebsformen auf die Naturverjüngung eines Traubeneichen-Buchen-Mischbestandes. Forstarchiv 79: 4 - 15.

Weinreich, A., and Grulke, M. 2001. Vergleich zwischen Nesterpflanzung und konventioneller Begründung von Eichenbeständen. Freiburger Forstliche Forschung 25: 41-54.

Wohlgemuth, T., Kull, P., and Wüthrich, H. 2002. Disturbance of microsites and early tree regeneration after windthrow in Swiss mountain forests due to the winter storm Vivian 1990. Forest Snow and Landscape Research 77(1/2): 17-47.

Zelman, D.P. 1961. Growth and formation of oak stands in relation to stand structure and density. [Russian]. Agrobiologija (Agrobiology). 5: 740 - 745 


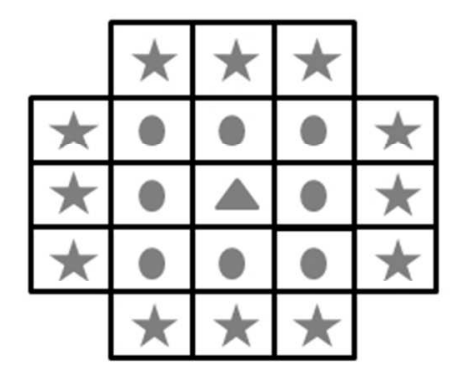

Outer oaks

Inner oaks

Central oak

(a)
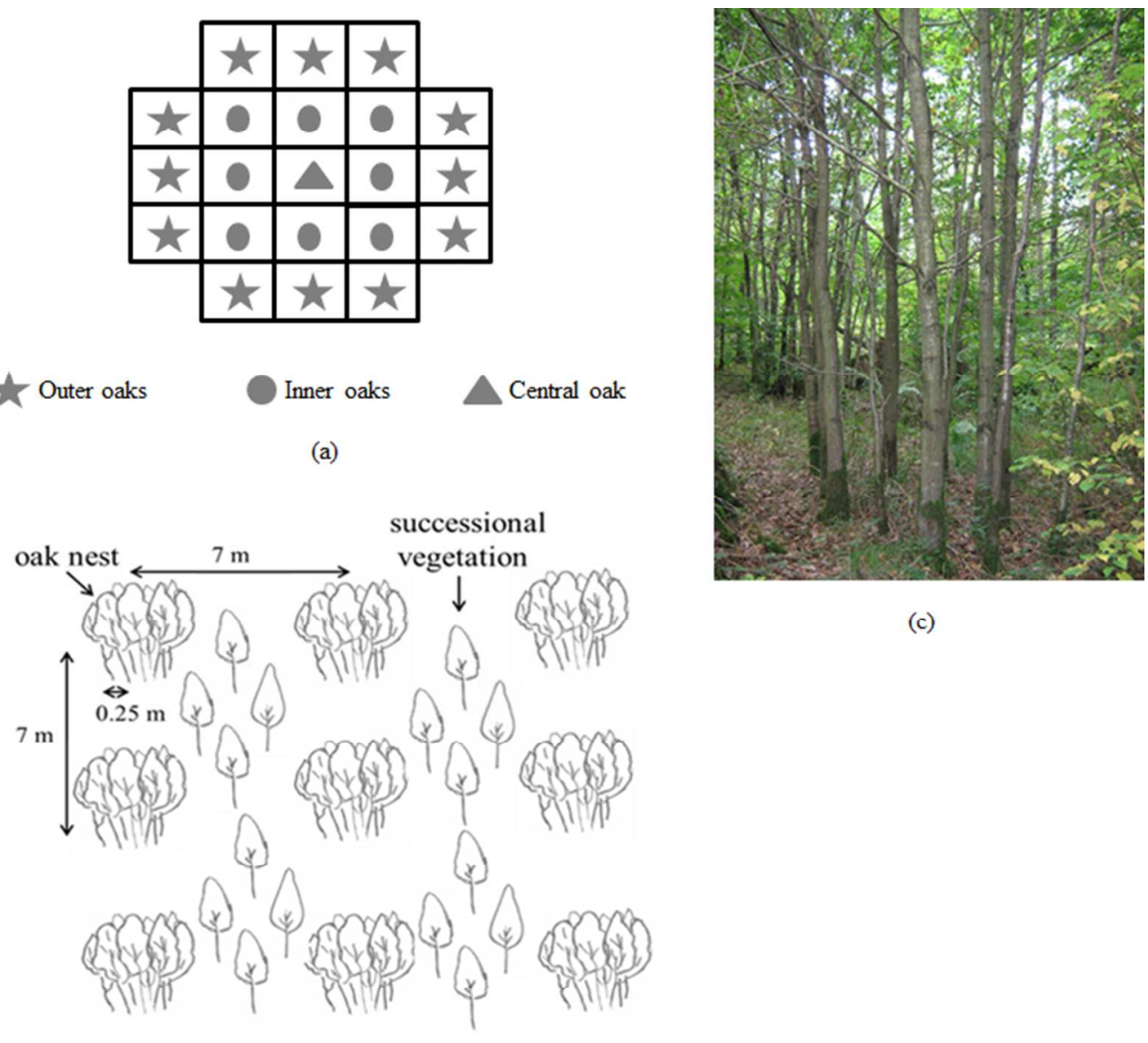

(c)

(b)

Fig. 1: (a) Szymanski's (1986) nest design; (b) $7 \times 7$ m spacing between the centres of nests were generally followed in German nest plantings; (c) 23-year-old nest planting in Leonberg-Stuttgart, BadenWuerttemberg, Germany.

$193 \times 184 \mathrm{~mm}(96 \times 96 \mathrm{DPI})$ 


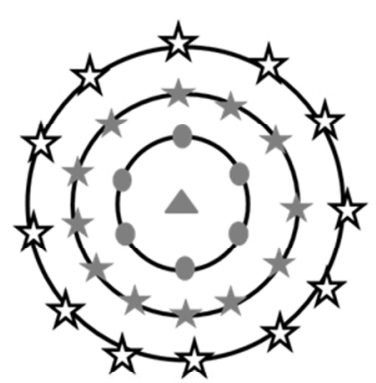

(a)

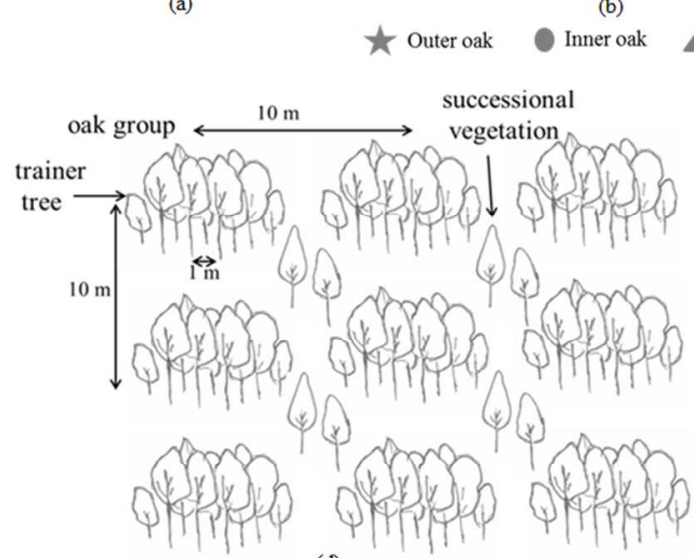

(d)

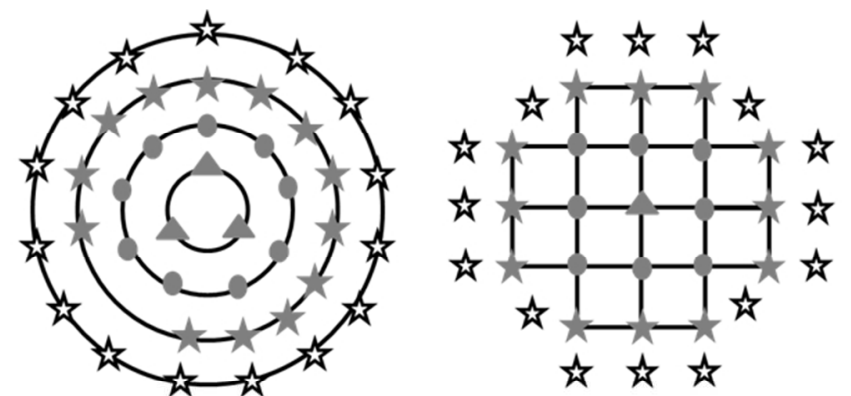

(c)

负 Trainer

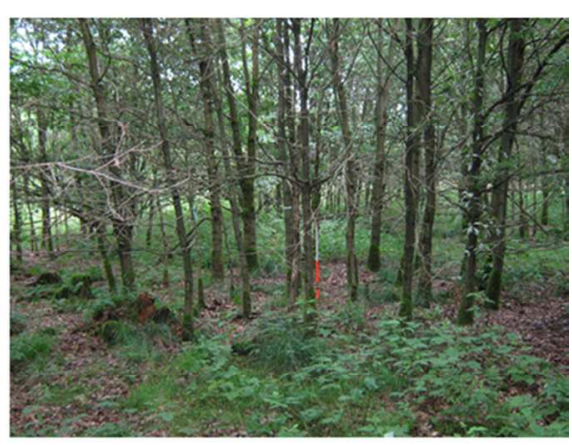

(e)

Fig. 2: (a, b, c) Gockel's (1994) group planting design with 3 variants; (d) $10 \times 10$ m spacing was commonly followed between the centres of groups; (e) 20-year-old group planting in Lerchenfeld-Schwarzenborn, Hesse, Germany.

$248 \times 189 \mathrm{~mm}(96 \times 96 \mathrm{DPI})$ 


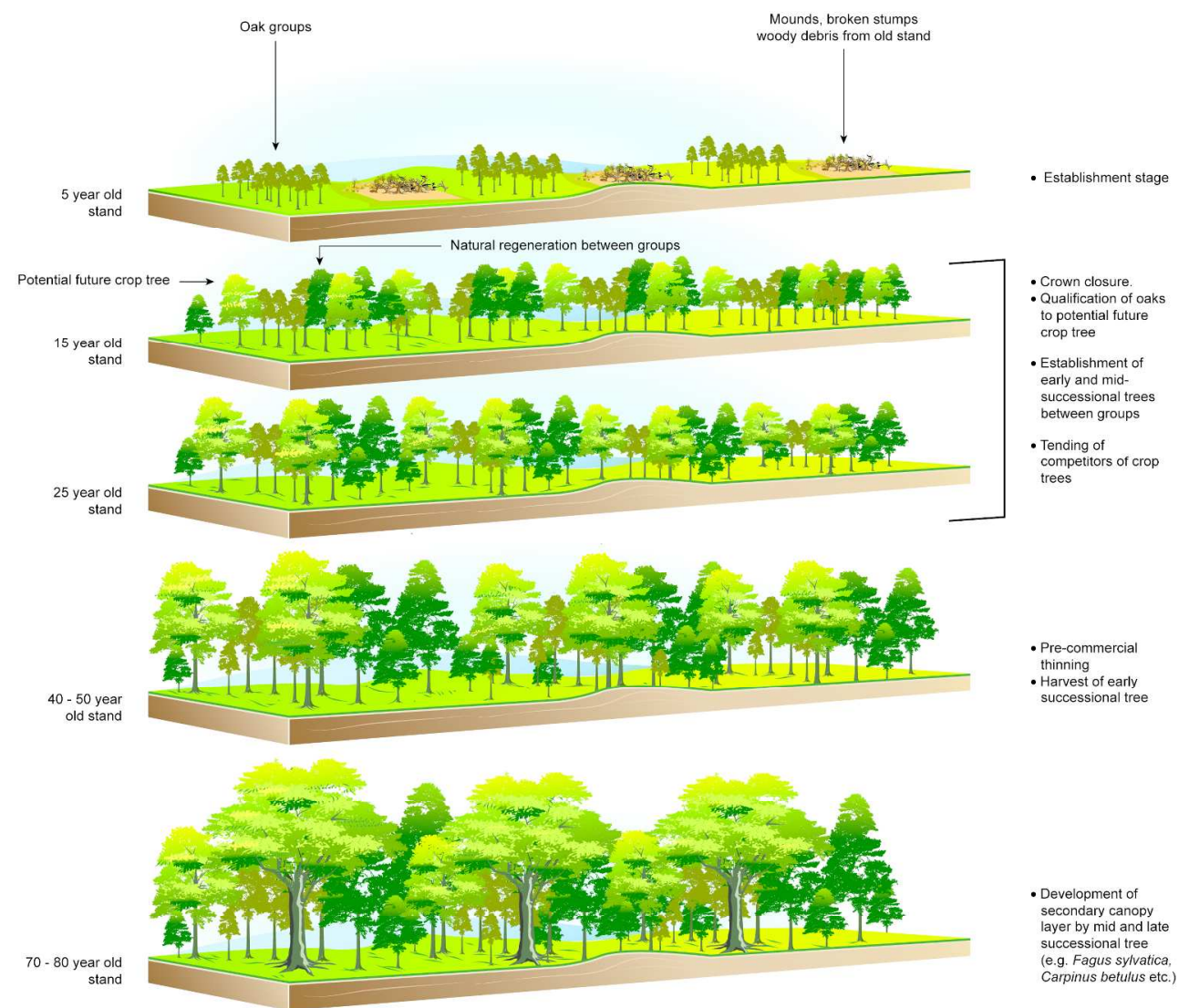

Fig.3: Possible development of forest structure in oak stands established through group planting. $240 \times 209 \mathrm{~mm}(300 \times 300$ DPI $)$ 